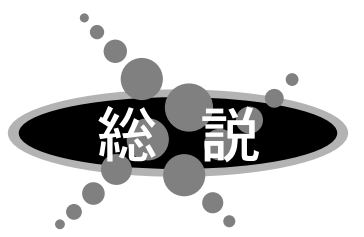

\title{
軟体動物アメフラシから発見された 多種同族体ペプチドの構造と生理作用
}

\author{
広島大学大学院総合科学研究科神経生物学研究室古川康雄 \\ マウントシナイ医科大学・神経科学 佐々木康成 \\ 広島大学大学院理学研究科生物科学専攻森下文浩 \\ 広島工業大学環境学部環境情報学科松島 治
}

\begin{abstract}
Neuropeptides are perhaps the most diverse intercellular signaling molecules in the animal kingdom. Owing to the high-throughput methodologies using the high-performance liquid chromatography as well as the mass spectrometry, the number of peptides identified from both vertebrates and invertebrates are increasing. In many cases, the multiple structurally related peptides which are unequivocally considered to be members of the same peptide family are found in the nervous system. We call such peptides the multiple family peptides. Here, we show the structure, distribution, and action of two kinds of multiple family peptides recently identified in a marine mollusc, Aplysia.
\end{abstract}

neuropeptide / blood vessels / invertebrate / Aplysia

\section{1. はじめに}

神経ペプチドは, 神経細胞が発現し, 神経細胞に働 くペプチドの総称である. 神経ぺプチドは最初から機 能的なシグナル分子として合成されるわけではなく, いったん神経ぺプチド以外の構造を含む前駆体タンパ クとして合成される. 前駆体タンパクから, 神経ペプ チドとなる部分が切り出され, 場合によってはカルボ キシル末端のアミド化などの分子修飾をうけてから機 能的なシグナル分子となる ${ }^{1}$. 神経ペプチド前駆体タン パクは1個から数個の神経ぺプチドを含む場合が多く, 構造が少しだけ異なるぺプチドを含む場合もよくある. たとえば, アヘン様ペプチドであるエンケファリンの 前駆体には, 7個のエンケファリン様ペプチドが存在し ているが，4個がメチオニンエンケファリンで，1個が ロイシンエンケファリンであり, 残りの 2 つメチ才 ニンエンケファリンのカルボキシル末端にアミノ酸が 2個あるいは3個付加された構造をもつ類似ぺプチドで ある ${ }^{2)}$. 無脊椎動物では, 非常に多くのぺプチドが $1 つ$ の前駆体タンパク遺伝子上にコードされている場合
がしばしばある.たとえば軟体動物アメフラシの

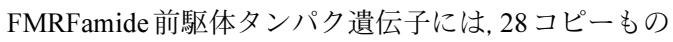
FMRFamideがコードされている ${ }^{3)}$. 前駆体タンパクに 同一の神経ペプチドが多数含まれていることには, 1つ の翻訳産物から多数のシグナル分子を合成できるとい う利点があると理解されている.

無脊椎動物の神経系から神経ペプチドの抽出を行う と, ほぼ同一といってもよいような短い類似ぺプチド が多種類みつかることがしばしば報告されており, 1 種 類の動物から発見される類似ぺプチドの数は, 脊椎動 物におけるそれよりも多(4),5). 一般に, ペプチド構造 に類似性があるものは同族体とみなされるので, 無脊 椎動物の神経系には, 多種類の類似ぺプチドからなる 同族体が存在することになる，以後，このような 1 種 類の動物の神経系に多数種類存在する同族体ぺプチド のことを, 特に多種同族体ぺプチドとよぶことにする. 本稿では, われわれの研究により構造が明らかにされ た軟体動物アメフラシの多種同族体ペプチドである AMRP族ペプチドとエンテリン族ペプチドに関する研 究を中心に紹介し, 多種同族体ぺプチドの特徴につい

\footnotetext{
Structure and Physiological Action of Novel Multiple Family Peptides of Aplysia

Yasuo FURUKAWA ${ }^{1}$, Kosei SASAKI ${ }^{2}$, Fumihiro MORISHITA ${ }^{3}$ and Osamu MATSUSHIMA ${ }^{4}$

${ }^{1}$ Laboratory of Neurobiology, Graduate School of Integrated Arts and Sciences, Hiroshima University

${ }^{2}$ Department of Neuroscience, Mount Sinai School of Medicine

${ }^{3}$ Department of Biological Science, Graduate School of Science, Hiroshima University

${ }^{4}$ Faculty of Environmental Studies, Hiroshima Institute of Technology
} 
Table 1 Structure of the AMRP or enterin family peptides in Aplysia

\begin{tabular}{cclc}
\hline AMRP & copy $\#$ & Enterin & copy \# \\
\hline AAPRFF & 1 & APGYSHSFV & 6 \\
GAPRFI & 1 & DPGFNHAFV & 1 \\
GAPRFL & 1 & ELNFQHAFV & 1 \\
GAPRFV & 2 & IPGYSHSFV & 1 \\
GPPRFI & 1 & QPGYSHSFV & 1 \\
GSPHFI & 1 & QPSFGHSFV & 2 \\
GSPRFF & 11 & QPSFTHAFV & 1 \\
QAPRFF & 2 & QPSYGHSFV & 1 \\
QAPRFI & 1 & QPSYTHAFV & 1 \\
SDPFFM & 1 & TPGYSHSFV & 3 \\
AMAPKFF & 1 & VPGYSHSFV & 8 \\
GAAPKFF & 1 & VPSFGHSFV & 1 \\
GQAPRFF & 1 & ADLGFTHSFV & 1 \\
LWVPGMV & 1 & AIPNFVHKFV & 1 \\
& & AIPSYSHNFV & 1 \\
& & GQPGYGNAFL & 1 \\
& & GSPGFSHSFV & 1 \\
& & RLPSYGHSFL & 1 \\
& & SSPFYGHNFV & 1 \\
& & VSPKYGHNFV & 1 \\
\hline
\end{tabular}

C-termini of all the peptides are amidated.

て述べてみたい.

\section{AMRPおよびエンテリン族ペプチドの構造と 組織分布}

ムラサキイガイ抑制性ペプチド (MIP) は, 二枚貝で あるムラサキイガイの神経節で初めて発見された筋収 縮抑制活性をもつペプチドである ${ }^{6)-8)}$. MIP様ぺプチド は, 基本的に 6 残基のアミノ酸からなり, カルボキシ ル末端側にPXF（V/I）という共通構造をもち, カルボ キシル末端のアミノ酸はアミド化されている5). MIPの 類似ペプチドは多くの軟体動物種から単離されてお り ${ }^{9)-12)}$, MIP 様ペプチドは軟体動物門における多種同 族体ぺプチドであると考えられる. われわれがアメフ ラシの多種同族体ぺプチドの研究を開始した時点では, MIP様ペプチドの前駆体タンパク構造は知られておら ず, 発見された多数種のペプチドが同じ翻訳産物に由 来するのかどうかは不明であった.

サントリー生物有機科学研究所の藤澤祐子博士, 南 方宏之博士との共同研究により,アメフラシの神経系 から MIP 様ペプチドの抽出を試みたところ，5種のア メフラシ MIP様ペプチド (AMRP) が精製できた ${ }^{13)}$. マ
ウントシナイ医科大学の Weiss 教授らとの共同研究に より, 前駆体タンパク遺伝子の cDNAをクローニング したところ, AMRP前駆体には, 精製された 5 種の AMRP の他に，9種のAMRPが含まれており，そのほとんど は1-2コピーであるが, GSPRFFamideは11コピーも含 まれることが明らかになった（Table 1)。AMRP には FFで終わるぺプチドが多く, このことがアメフラシの MIP様ペプチドの特徵である. 前駆体から予測される 14 種類の AMRPが実際に発現していることは, イリノ イ大学の Sweedler 博士との共同研究により, MALDITOF-MS を使った解析から明らかになった. アメフラ シの中枢神経系は, 口球神経節, 脳神経節, 側神経節, 足神経節，および腹部神経節に分かれている. 免疫組 織化学とin situ八イブリダイゼーションによ り AMRP含有ニューロンの分布を調べてみると, 側神 経節と腹部神経節にAMRP含有ニューロンが特に多く 存在することがわかった.ささまざまな末梢組織にも AMRPを含む神経線維が確認されたが, なかでも血管 壁には多くの神経線維の分布がみられた ${ }^{13)}$.

エンテリン族ペプチドは, アメフラシ消化管および 中枢神経系から精製された $9 / 10$ 残基のアミノ酸からな るぺプチドであり，腸管神経系 (the enteric nervous system）に局在することからエンテリンと命名した ${ }^{14)}$. エンテリン前駆体タンパク遺伝子のcDNAをクローニ ングしたところ, 単一の前駆体タンパクに 20 種類, 35 個のエンテリンが含まれていることがわかった (Table 1). AMRP族ペプチドの場合と同様に, 異なるエンテ リンのコピー数には違いがあり, APGYSHSFVamide と VPGYSHSFVamideのコピー数が最も多い. また, 20 種 類のエンテリンが実際に発現していることは MALDITOF-MS により確認された. エンテリン含有ニューロ ンの分布はAMRP含有ニューロンの分布とはあきらか に異なり, 口球神経節と足神経節に多くのエンテリン 含有ニューロンが存在することがわかった. 一方, 末 梢組織でみてみると, 消化管のほかに血管系にもエン テリン含有神経線維が分布していた.

\section{3. アメフラシの血管系一多種同族体ペプチドの 生理作用研究におけるモデルシステム}

AMRP／エンテリン族ペプチドを含有する神経がア メフラシ血管に分布することから, これらの多種同族 体ペプチドが血液循環調節にかかわることが考えらる. アメフラシの血液循環系は開放血管系であり, 心臓か ら送り出された血液（正確にはへモリンフ）は3本の 大動脈を通って末梢組織に運ばれるが, 末梢組織から 心臓へ血液を戻す静脈系はない（Fig. 1)。 そこで，こ の動物の心臓からおもに頭部へ血液を運ぶ前部大動脈 
A

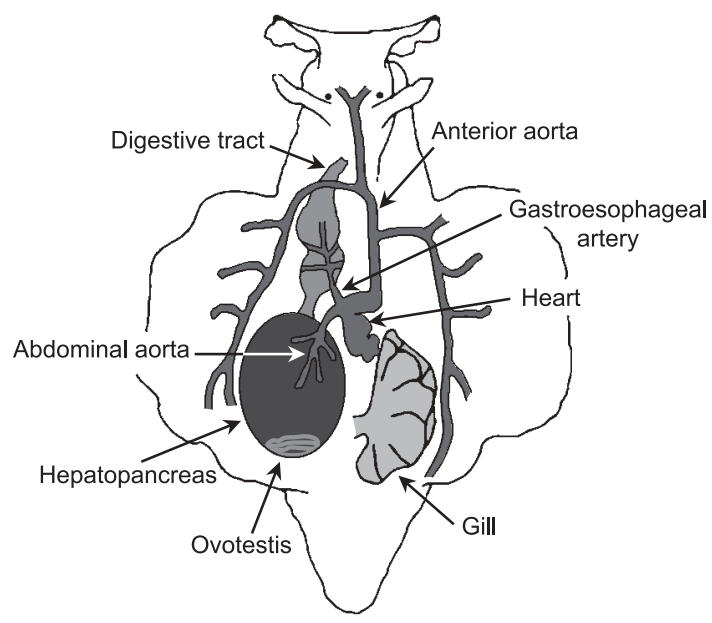

B

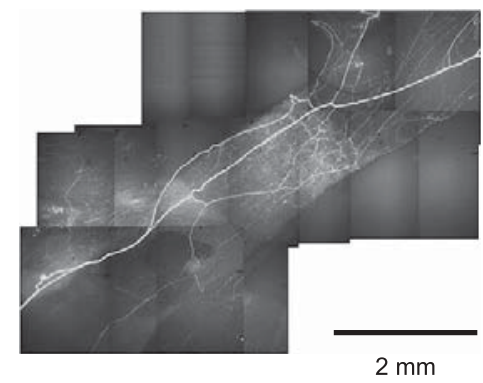

Fig. 1 Arterial system of Aplysia. A: Schematic drawing of Aplysia arterial system. There are three main arteries: the anterior aorta, the abdominal aorta, and the gastroesophageal artery. B: AMRP-immunopositive fibers in the abdominal aorta. Middle part of this picture showing rich immunopositive branches corresponds to the region containing vasoconstrictor muscle.
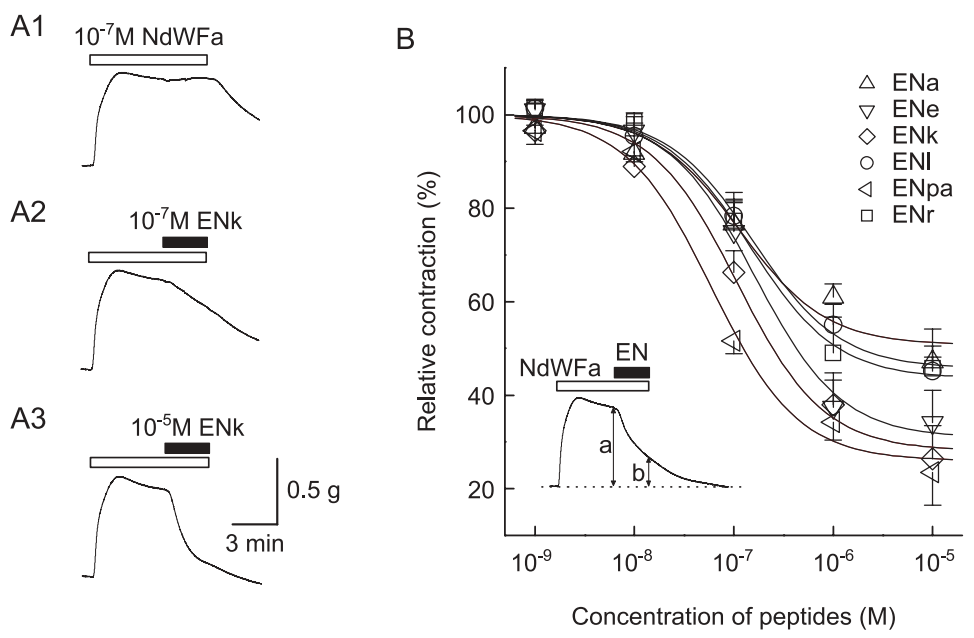

Fig. 2 Effects of enterins on the tonic contraction of the anterior aorta ${ }^{16}$. A: Relaxation of the tonic contraction of the anterior aorta by enterin. The tonic contraction was evoked by the application of NdWFamide. B: The concentration-response relationship of enterins. ENa: VSPKYGNFVamide, ENe: ADLGFTHSFVamide, ENk: APGYSHSFVamide, ENI: ELNFQHAFVamide, ENpa: APSFGHSFVamide, ENr: DPGFNHAFVamide. The contraction amplitude in the presence of enterin ( $b$ in the inset) was divided by the contraction amplitude before the application of enterin ( $a$ in the inset), and the mean \pm SE (standard error) were plotted against the concentrations of enterins.

(anterior aorta) と, 腹部大動脈（abdominal aorta）の基 部にあり末梢各部への血液分配を調節する働きをする 血管括約筋 (vasoconstrictor muscle) に対する AMRP/エ ンテリン族ペプチドの作用を調べてみた。

予備実験により，エンテリンに血管弛緩作用がある ことがわかったが, 摘出した前部大動脈の収縮状態は 標本によって著しいばらつきがあるため, アメフラシ 心拍動増強ぺプチドであるNdWFamide ${ }^{15)}$ を前部大動脈
に作用させて緊張性収縮を惹起した血管に対するエン テリンの作用を検討した ${ }^{16)}$. その結果, いくらかの効 力の違いはあるものの, 調べた 6 種類のエンテリンは すべて血管弛緩作用を示した（Fig. 2）． $\mathrm{EC}_{50}$ ※はぺプ

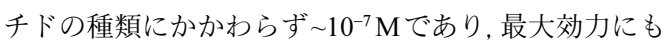
統計的有意差は検出されなかった。 この結果は, エン テリン族ペプチドが, 少なくとも前部大動脈の収縮抑 制作用に関しては攵長なシグナル分子であることを示 
A1

$10^{-7} \mathrm{M} \mathrm{ENpa}$

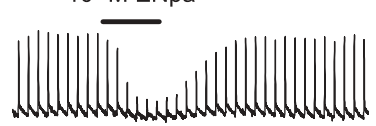

A2

$10^{-7} \mathrm{M} \mathrm{ENpa}$
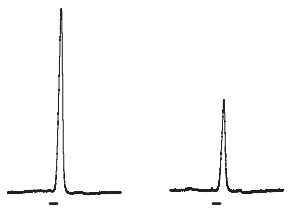

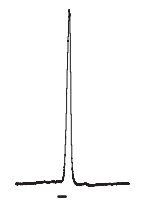

B1

$10^{-7} \mathrm{M}$ GSPRFFa

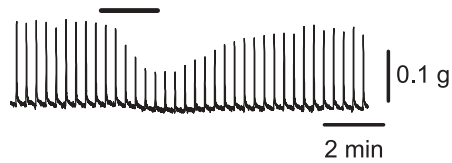

B2

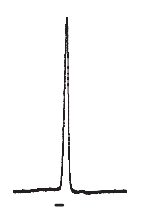

Fig. 3 Effects of enterin (ENpa) and AMRP (GSPRFFamide) on the nerve evoked contraction (A1, B1) or the acetylcholine (ACh)induced contraction $(A 2, B 2)$ of the vasoconstrictor muscle ${ }^{18}$. Note enterin inhibits both the nerve-evoked and the $A C h$ induced contractions of the muscle, while the AMRP depresses the nerve-evoked contraction but not the ACh-induced contraction. In this preparation, the ACh-induced contraction is rather augmented by AMRP. The figure was modified from ref. 18 .

唆している.

血管平滑筋細胞における電気生理, 薬理学的実験か ら, エンテリンはおもに4-AP (アミノピリジン) 感受 性 $\mathrm{K}^{+}$チャネル※を活性化することで筋細胞膜の過分極 をもたらし，興奮性神経の働きによる血管収縮を抑制 することが明らかになった ${ }^{16)}$.一方, NdWFamideによ る血管収縮に対するエンテリンの抑制作用は4-APによ りまったく阻害されなかったので，エンテリンの抑制 作用には，筋細胞の膜電位変化だけでは説明できない 成分があることも明らかになった ${ }^{16)}$. 腹部大動脈括約 筋は, 腹部神経節に存在する運動ニューロンによる神 経支配をうけているが17)，エンテリンは括約筋を過分 極させ, 興奮性接合部電位の減少をもたらし，括約筋 収縮を抑制した ${ }^{18)}$ ．また，エンテリンは括約筋に対す る興奮性神経伝達物質候補であるアセチルコリンによ る収縮も同様に抑制した（Fig. 3A）。

AMRP族ぺプチドの作用を同様に調べたところ, AMRP は $10^{-5} \mathrm{M}$ という高濃度でも NdWFamide による 前部大動脈収縮をまったく抑制しなかった. 神経刺激に よる一過性収縮に対しても $10^{-7} \mathrm{M}$ までは無効で, $10^{-6} \mathrm{M}$ 以上の高濃度を与えると筋収縮を 20-30\%程度抑制し た. 神経笳接合部電位に対する AMRPの作用を検討し たところ，AMRPは興奮性接合部電位を選択的に抑制 することがわかった，AMRP族ぺプチドは，腹部大動 脈括約筋の静止電位を変化させることなく興奮性接合 部電位を減少させ括約筋収縮を抑制したが, アセチル コリンによる収縮はまったく抑制しなかった（Fig. 3B）。
これらの結果から，AMRPはもっぱらシナプス前抑 制により筋収縮を抑制し, エンテリンはシナプス前抑 制の他に, 筋細胞に直接作用して収縮を抑制するもの と考えられる ${ }^{18)}$. これらのペプチドの働きは, アメフ ラシの血管壁の固さを調節し, 特定部位への血流量を 増減させるものと思われる

\section{4. 多種同族体ペプチドが多種である意味合いは なにか}

多種同族体ぺプチドの機能を丹念に調べた例として， アメフラシの摂食行動にかかわる筋肉である歯舌付属 閉筋（ARC）における buccalin と myomodulinの作用が あげられる19)-23). myomodulinには9種類の類似ぺプチ ドが知られているが，そのうちの7種は同一の前駆体 タンパク遺伝子上にコードされており, 同じニューロ ンに含まれていると考えられる222. 残りの 2 種は, 別 の遺伝子にコードされており, ペプチドを発現する ニューロンも異なることが最近明らかにされた ${ }^{24)} .9$ 種 の myomodulinはARCの収縮調節作用という点ではまっ たく圥長であり,このぺプチド族の多種性は, 遺伝子 重複によって増えた祖先型 myomodulinに生じた中立的 変異の結果ではないかと推察されている ${ }^{23)}$. われわれ が同定したAMRP およびエンテリン族ぺプチドも，ア メフラシ血管の収縮性調節という機能に関する限り基 本的に呪長なシグナル分子と考えられる. これらの結 果から, 少なくともある特定の末梢器官においては, 多 種同族体ぺプチドが多種であることによる機能的意味 
A

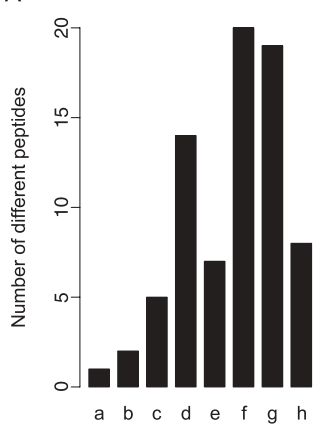

B

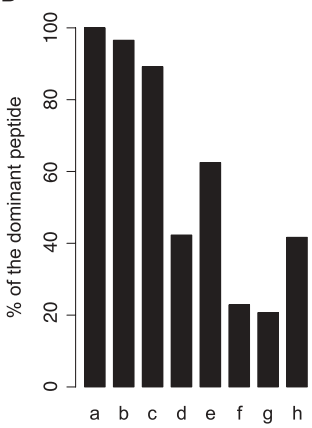

Fig. 4 Comparison of the number of coded peptides (A) and the percentage of the dominant peptide (B) among some Aplysia neuropeptide precursors. a: APGWamide $^{28)}$, b: FMRFamide ${ }^{3)}$, c: PRQFVamide ${ }^{27)}$, $\mathrm{d}: \mathrm{AMRP}^{13)}$, e: myomodulin ${ }^{22)}$, f: enterin ${ }^{14)}, \mathrm{g}$ : buccalin ${ }^{21)}$, h: FCAP ${ }^{29}$. The length of the peptides for a-h are 4, 4, 5, 6/7, 7/8, 9/10, 10-12, and 12/13, respectively. The length of the precursor protein for a-h are $209,597,862,735,370,837,505$, and 742 , respectively.

合いは薄いものと思われる.

ただし，多種同族体ペプチドが常に罙長なシグナル 分子であると結論することはできない.アメフラシの 末梢組織において, 類似ぺプチドの効力差が標的器官 によって異なる場合があることが知られているし13)，ア メフラシの近縁種とされるアマクサアメフラシの血管 では, 異なる $\mathrm{AMRP}$ 族ペプチドの $\mathrm{EC}_{50}$ に 1 桁以上の差 がみられるものがある ${ }^{25}$. これらの事実は，ある類似 ペプチドに対してより親和性が高い受容体があり，そ のような受容体を特異的に発現する標的器官があるこ とを示唆する. この点に関して, 巻き貝であるアカニ シの口筋に抢ける興味深い報告がある ${ }^{26)}$. FMRFamide と FLRFamideは, ほとんどの標的器官において質的に同じ 作用を示すが4)，アカニシの歯舌伸出筋ではFMRFamide のみが筋収縮の増強をもたらし，拮抗筋である歯舌牽 引筋ではFLRFamideのみが収縮を増強する ${ }^{26)}$. この結 果は, わずか 1 アミノ酸が違うだけの 4 残基ペプチド を識別する 2 種の受容体が別々の筋肉に発現している ことを示している

そもそも，なぜあるぺプチドが多種になるのだろう か.アメフラシのFMRFamide前駆体タンパクには28個 もの FMRFamide が含まれるが, 類似ぺプチドである FLRFamide はわずかに 1 個しか存在しない3). また, 最 近われわれが構造決定したPRQFVamideの前駆体タン パクには33個ものPRQFVamideが含まれるのに, その 類似ペプチドは 4 個しかない27). これらの前駆体タン パク遺伝子では, シグナル分子を多数化する方向への

変異は残ったが，シグナル分子を多様化する方向への 突然変異は抑元られたようである。一方, AMRPやエ ンテリン族ペプチド前駆体タンパクのように多種類の 類似ペプチドを含むものでは, 生じた突然変異が特に 負の淘汰を受けることなく残っているようである。こ のような違いを生んだ 1つの要因は, 神経ペプチドの 長さではないだろうか. アメフラシの神経ペプチド前 駆体タンパク遺伝子のうち, ペプチドのコピー数が比 較的多いものを選び, ペプチドの種類数と全コピー数 に対する最もコピー数の多いペプチドの割合を比べて みると, 短い神経ペプチドをコードする前駆体では類 似ペプチドの種類数が少なく, 抢もなぺプチドが占め る割合が高い傾向があることがよくわかる（Fig. 4).

\section{5. おわりに}

神経ペプチドは, 動物界に存在する最も多種多様な 細胞間シグナル分子であり, ペプチドホルモンとして だけでなく,アセチルコリンなどのような古典的神経 伝達物質と同時に放出される補助伝達物質として, 通 常の神経伝達においても働いていることがさまざまな 系で明らかになってきている1). 本稿で紹介したAMRP/ エンテリン族ペプチドを含有するニューロンの多くは 神経分泌細胞ではないので，これらの多種同族体ペプ チドも神経伝達物質として働くものと思われる.

神経ペプチドがシグナル分子として働くためには, そ れらが作用する受容体が必要である. 4-5 残基程度のア ミノ酸からなる短いぺプチドの受容体の場合, 特異性 を確保するためには，拈そらくペプチド全体を認識す る受容体が必要となるものと思われる，そのような受 容体を進化させた場合, ペプチドにアミノ酸置換をも たらす突然変異は有害であり除去されやすいものと想 像される. より長い神経ペプチドの場合, その構造の 一部だけを特異的に認識する受容体が出現することも 可能であり, 事実, 本稿で述べたアメフラシ血管のエ ンテリン受容体は類似ぺプチドをほとんど区別しない. そのような受容体を進化させた場合は, ペプチド側の 突然変異が中立的な変異として残りやすいものと想像 される，また，中立的変異によるシグナル分子の多様 化が, 認識部位がわずかに異なる受容体の出現をうな がすこともあったかもしれない. アメフラシの多種同 族体ペプチドは, シグナル分子としての神経ペプチド やその受容体の進化を考えてみる上でも興味深い素材 となるだろうと考えている.

\section{文 献}

1) Strand, F. L. (1999) Neuropeptides: Regulators of physiological processes. The MIT Press. 
2) Noda, M., Furutani, Y., Takahashi, H., Toyosato, M., Hirose, T., Inayama, S., Nakanishi, S. and Numa, S. (1982) Nature 295, 202-206.

3) Taussig, R. and Scheller, R. H. (1986) DNA 5, 453-461.

4) Kobayashi, M. and Muneoka, Y. (1990) Zool. Sci. 7, 801814.

5) 宗岡洋二郎 (1998) 化学と生物 36, 153-159.

6) Hirata, T., Kubota, I., Iwasawa, N., Takabatake, I., Ikeda, T. and Muneoka, Y. (1988) Biochem. Biophys. Res. Commun. 152, 1376-1382.

7) Fujisawa, Y., Kubota, I., Ikeda, T., Minakata, H. and Muneoka, Y. (1991) Comp. Biochem. Physiol. 100C, 525531.

8) Fujisawa, Y., Takahashi, T., Ikeda, T., Muneoka, Y., Kubota, I., Minakata, H., Nomoto, K., Nose, T. and Miki, W. (1993) Comp. Biochem. Physiol. 106C, 261-267.

9) Ohtani, M., Muneoka, Y., Takahashi, T. and Teranishi, H. (1995) Acta Biol. Hung. 46, 449-452.

10) Ikeda, T., Yasuda-Kamatani, Y., Minakata, H., Kenny, P. T. M., Nomoto, K. and Muneoka, Y. (1992) Comp. Biochem. Physiol. 101C, 245-249.

11) Ikeda, T., Kiss, T., Hiripi, L., Fujisawa, Y., Kubota, I. and Muneoka, Y. (1991) Peptide Chem. 1990, 357-362.

12) Ikeda, T., Minakata, H., Fujita, T., Muneoka, Y., Kiss, T., Hiripi, L. and Nomoto, K. (1993) Peptide Chem. 1992, 576-578.

13) Fujisawa, Y., Furukawa, Y., Ohta, S., Ellis, T. A., Dembrow, N. C., Li, L., Floyd, P. D., Sweedler, J. V., Minakata, H., Nakamaru, K., Morishita, F., Matsushima, O., Weiss, K. R. and Vilim, F. S. (1999) J. Neurosci. 19, 9618-9634.

14) Furukawa, Y., Nakamaru, K., Wakayama, H., Fujisawa, Y., Minakata, H., Ohta, S., Morishita, F., Matsushima, O., Li, L., Romanova, E., Sweedler, J. V., Park, J. H., Romero, A., Cropper, E. C., Dembrow, N. C., Jing, J., Weiss, K. R. and Vilim, F. S. (2001) J. Neurosci. 21, 8247-8261.

15) Morishita, F., Nakanishi, Y., Kaku, S., Furukawa, Y., Ohta, S., Hirata, T., Ohtani, M., Fujisawa, Y., Muneoka, Y. and Matsushima, O. (1997) Biochem. Biophys. Res. Commun. 240, 354-358.

16) Sasaki, K., Fujisawa, Y., Morishtia, F., Matsushima, O. and
Furukawa, Y. (2002) J. Exp. Biol. 205, 3525-3533.

17) Mayeri, E., Koester, J., Kupfermann, I., Liebeswar, G. and Kandel, E. R. (1974) J. Neurophysiol. 37, 458-475.

18) Sasaki, K., Morishita, F. and Furuakwa, Y. (2004) J. Exp. Biol. 207, 4439-4450.

19) Cropper, E. C., Tenenbaum, R., Kolks, M. A. G., Kupfermann, I. and Weiss, K. R. (1987) Proc. Natl. Acad. Sci. USA 84, 5483-5486.

20) Cropper, E. C., Miller, M. W., Tenenbaum, R., Kolks, M. A. G., Kupfermann, I. and Weiss, K. R. (1988) Proc. Natl. Acad. Sci. USA 85, 6177-6181.

21) Miller, M. W., Beushausen, S., Cropper, E. C., Eisinger, K., Stamm, S., Vilim, F. S., Vitek, A., Zajc, A., Kupfermann, I., Brosius, J. and Weiss, K. R. (1993) J. Neurosci. 13, 3346-3357.

22) Miller, M. W., Beushausen, S. Vitek, A., Stamm, S., Kupfermann, I., Brosius, J. and Weiss, K. R. (1993) J. Neurosci. 13, 3358-3367.

23) Brezina, V., Bank, B., Cropper, E. C., Rosen, S., Vilim, F. S., Kupfermann, I. and Weiss, K. R. (1995) J. Neurophysiol. 74, 54-72.

24) Proekt, A., Vilim, F. S., Alexeeva, V., Brezina, V., Friedman, A., Jing, J., Li, L., Zhurov, Y., Sweedler, J. V. and Weiss, K. R. (2005) J. Neurosci. 25, 9637-9648.

25) Sasaki, K., Shimizu, Y., Abe, G., Fujisawa, Y., Morishita, F., Matsushima, O. and Furukawa, Y. (2002) Peptides 23, 1959-1965.

26) Yanagawa, M., Fujiwara, M., Takabatake, I., Muneoka, Y. and Kobayashi, M. (1988) Comp. Biochem. Physiol. 90C, 73-77.

27) Furukawa, Y., Nakamaru, K., Sasaki, K., Fujisawa, Y., Minakata, H., Ohta, S., Morishita, F., Matsushima, O., Li, L., Alexeeva, V., Ellis, T. A., Dembrow, N. C., Jing, J., Sweedler, J. V., Weiss, K. R. and Vilim, F. S. (2003) J. Neurophysiol. 89, 3114-3127.

28) Fan, X., Croll, R. P., Wu, B., Fang, L., Shen, Q., Painter, S. D. and Nagle, G. T. (1997) J. Comp. Neurol. 387, 53-62.

29) Sweedler, J. V., Li, L., Rubakhin, S. S., Alexeeva, V., Dembrow, N. C., Dowling, O., Jing, J., Weiss, K. R. and Vilim, F. S. (2002) J. Neurosci. 22, 7797-7808. 


\section{軟体動物アメフラシから発見された多種同族体ペプチドの構造と生理作用}

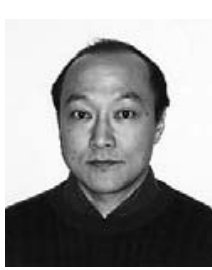

古川康雄

古川康雄（ふるかわ やすお）

広島大学大学院総合科学研究科教授

連絡先：干739-8521 東広島市鏡山 1-7-1

E-mail: yasfuru@hiroshima-u.ac.jp

佐々木康成（ささき こうせい）

マウントシナイ医科大学神経科学博士研究員

連絡先: Department of Neuroscience, Mount Sinai School of Medicine, Box 1065, One Gustave L. Levy Place, New York, NY 10029

E-mail: Kosei.Sasaki@mssm.edu

森下文浩（もりした ふみひろ）

広島大学大学院理学研究科生物科学専攻助手

連絡先：干 739-8526 東広島市鏡山 1-3-1

E-mail: fumi45@hiroshima-u.ac.jp

松島 治（まつしま おさむ）

広島工業大学環境学部環境情報学科教授

連絡先 : = 731-5193 広島市佐伯区三宅 2丁目 1-1

E-mail: matsu88@cc.it-hiroshima.ac.jp 